the Anti-Noise League and is being held at the Science Museum, South Kensington, during this month. The opening ceremony was held in the lecture theatre, and was attended by some two hundred guests. The chair was taken by Lord Horder, chairman of the Council of the Anti-Noise League. Mr. MacDonald in his speech opening the exhibition said that formerly a person who confessed that he was troubled by noise was put down as an irreparable crank; but now it is rightly regarded that noise is something that ought not to be tolerated by any decent man or woman. He suggested that their campaign against nerve jarring should be regarded as a great movement in æstheticism. It is the duty of all to co-ordinate in the protection of life from jars of the eye and the nerves-jars of the complete human personality. Sir Henry Richards, chairman of the Executive Committee of the Anti-Noise League, in moving a vote of thanks to the Prime Minister, said that the League is an educational body and the exhibition is intended to show to the public the means of escape from noise. The Prime Minister made a short tour of the exhibition and inspected among other things a silenced pneumatic road-drill, a silenced motor-cycle engine, a ripple tank illustrating the behaviour of sound-waves from a speaker in the House of Commons and several models demonstrating the scientific principles of the reduction of noise from machinery and in buildings.

\section{The Health of Sunderland and County Durham}

Dr. G. F. WALken, of Sunderland, in a letter to The Times last December, made an appeal that the deterioration of health of a section of the population in Sunderland and adjacent districts in County Durham, where unemployment has been severe and prolonged, was serious, and deserved more national consideration. In consequence of statements made in Dr. Walker's letter, the Ministry of Health instituted an inquiry by Dr. Pearse, Ministry of Health, Dr. Glover, Board of Education, and Mr. Grant, Ministry of Health, whose report has now been issued ("Report of an Inquiry into the Effects of Existing Economic Circumstances on the Health of the Community in the County Borough of Sunderland and certain districts of County Durham. London : H.M. Stationery Office, 1935. 9d. net). The matter of this report is too lengthy to quote in detail, but is summarised in the concluding paragraph. While admitting that there may be some slight deterioration of health and small increase in the incidence of certain diseases, the investigators state that "We are unable to accept Dr. Walker's statement that there has been in this area a 'substantial and progressive deterioration in public health" ".

\section{Technological Advances of the Past Twenty-five Years}

Sir Frank Smith, secretary of the Department of Scientific and Industrial Research, spoke on June 3 at a special Jubilee luncheon, held under the auspices of the Society of Engineers, on "Some Significant Technological Achievements of the King's Reign" Sir Frank dealt with four outstanding types of achievement of the period. The first was the advances in medicine which have prolonged our lives; the second was the more complete harnessing of the electron, an achievement which has given birth to industries unknown in 1910 ; the third was the fixation of nitrogen, an achievement which has overthrown the menace to our food supplies resulting from diminishing quantities of Chile nitrate; and finally, the production of new steel cutting tools, which has largely affected mechanisation, the price of manufactured goods and the leisure of man. Speaking of the industrial applications arising from the discovery of the electron, and the researches of Sir J. J. Thomson and Lord Rutherford and others on the structure of the atom and on matter in general, Sir Frank said : "When the King came to the throne there was not one listener in the world, for there was no broadcasting station. To-day in this country alone there are over 7 million people with licensed receivers. There are millions of thermionic valves in use, and on his Jubilee day the King spoke via millions of thermionic valves to hundreds of millions of his subjects. The radio engineer was in charge, and by the simple operation of switches, millions and millions of electrons played the parts arranged for them beforehand." The turnover in the radio broadcasting industry, which did not exist twenty-five years ago, was more than 20 millions sterling last year. The harnessing of the electron has been, in Sir Frank's opinion, one of the greatest achievements of the King's reign. It enables one person to speak to and be heard by the whole of the civilised world; it has increased entertainment and amusement through the 'talkies', and it has enabled our homes, our roads and our public buildings to be illuminated in a manner which many would have thought impossible twenty-five years ago.

\section{British Standards Institution}

THe annual meeting of the British Standards Institution was held on May 28, with Dr. E. F. Armstrong in the chair, who, in presenting the report, said the year's work showed marked progress in every section. He laid stress on the fact that more than 150,000 copies of the British Standard Specifcations have been sold and distributed during the year, an increase over last year of 23,000 , and that there are now 700 committees holding more than 1,000 meetings a year, the total membership exceeding 5,000 . The machinery of the B.S.I. is such that no section of industry need fear that its considered views will not receive the fullest consideration, or that a British Standard Specification would be issued in the face of soundly based objection. Moreover, it has been definitely stated that the Institution does not contemplate setting itself up as a testing authority. Mr. W. Reavell, a past-president of the Institution of Mechanical Engineers, has been elected chairman for the ensuing year. He was one of the first to recognise the necessity for the co-ordination of the work of mechanical standardisation, in which the Institution of Mechanical Engineers is taking a leading part. Perhaps one of the most important results of the year's work is the increasing success of the interImperial co-operation which is now so firmly 
established. Australia has a standards organisation with 500 committees manned by more than $\mathbf{4 , 5 0 0}$ individuals, and during the past year 75 industrial standards have been issued and 20 more are out for public criticism. British Standard Specifications are good propaganda for British trade, and it is to be noted that more than 12,000 copies have been sent to diplomatic and trade commissioners in all parts of the world, so that they may maintain complete sets which may be consulted by those desiring information regarding British products, as represented by British Standard Specifications. The Government continues its whole-hearted support of the B.S.I. as the national standardising body in Great Britain.

\section{Cider Tasting Day at Long Ashton}

The Open Field Day at the Research Station, Long Ashton, near Bristol, was held on May 2. A large and distinguished company of growers, brewers, men of science and administrators met to exchange views, inspect the laboratories and outdoor plots, and to exercise a discretionary taste upon the samples of cider prepared under controlled conditions by the National Fruit and Cider Institute. Representatives from Canada, South Africa, India, and the United States were present. The function has retained its atmosphere of informality and free intercourse throughout its thirty years, in spite of the fact that visitors have increased in number about a hundredfold since the first meeting of twenty-five members. The desire to take full advantage of the educational opportunities of the day has also grown. The ciders of 1934 were definitely above the average in quality, but were slightly inferior to the superlative product of the previous year-one cannot expect equal quality from two heavy crops in succession. An exhibit of centrifuging as a method of controlling fermentation attracted much interest, whilst experiments and out. door demonstrations on pomology, plant nutrition, fruit breeding, economic mycology and entomology, willow culture and fruit and vegetable preservation, were also shown. The Agricultural Advisory Centre, Berkeley Square, Bristol, and the National Mark organisation provided additional exhibits.

\section{Soil Research in Scotland}

AT a Scottish joint meeting of the Chemical Society, Institute of Chemistry and Society of Chemical Industry held in Aberdeen on May 17-18, at which Prof. Alexander Findlay presided, the work being carried out at the Macaulay Institute for Soil Research provided the subject for discussion. Dr. Ian M. Robertson read a paper entitled "The Agricultural Utilisation of Peat Land", in which the geology of peat formation, the physical and biological properties of peat and their relation to land reclamation were described. Members of the three Societies had an opportunity to visit the Macaulay Institute for Soil Research on May 18, when the Director, Dr. W. G. Ogg, and his staff, described the particular branches of soil research carried out in Scotland. These included geological work on soils, soil survey work, the investigation of soil fertility, and advisory work among farmers.

\section{South Africa: Progress of Twenty-five Years}

THE special South Africa supplement of The Times, presented with the issue of May 31, deserves mention for its wealth of interest and its authoritative articles. Published to commemorate the silver jubilee of the Union of South Africa, the supplement reviews the progress of the Dominion during the last twenty-five years. Articles on agriculture, mining, migration, education, wild-life and native affairs are particularly noteworthy; but other sides of South African life, such as finance, architecture, sport, communications and holiday resorts are not omitted. Altogether, the supplement, which runs to thirty pages and is illustrated with maps and photographs, may be regarded as an important 'volume' on all aspects of South Africa, and one of permanent value.

\section{Malaria in Ceylon}

THE seriousness of the epidemic of malaria that has been raging in Ceylon may be realised from the fact that 74,000 deaths are attributed to this disease during the six months, November--April. Up to the end of April, nearly two million rupees were expended in relief, exclusive of sums for medical treatment. The situation has afforded an opportunity to test on a large scale the value of quinine and of synthetic antimalarial drugs, and the report thereon when published should prove of great value.

\section{British Standard Density Hydrometers}

The Hydrometer Sub-Committee of the British Standards Institution has prepared a draft specifcation for British standard density hydrometers and tables for use with the hydrometers. The draft specification and tables are now being circulated to interested bodies by the Institution for criticism prior to their final publication. The Institution would welcome comments on the proposals from as wide a circle as possible, and a copy of the draft specification and tables will be forwarded to anyone interested on application to the Director, British Standards Institution, 28 Victoria Street, London, S.W.1.

\section{Nutrition Advisory Committee}

THE Minister of Health and the Secretary of State for Scotland have appointed a Nutrition Advisory Committee to "inquire into the facts, quantitative and qualitative, in relation to the diet of the people, and to report as to any changes therein which appear desirable in the light of modern advances in the knowledge of nutrition". The members of the Committee are : Lord Luke (chairman), Mrs. Eleanor Barton, Mr. J. N. Beckett, Dr. G. F. Buchan, Prof. E. P. Catheart, Mr. R. R. Enfield, Dr. J. Alison Glover, Dr. J. M. Hamill, Dr. A. Bradford Hill, Sir F. Gowland Hopkins, Dr. Donald Hunter, Prof, E. Mellanby, Sir John Boyd Orr, Mr. E. C. Ramsbottom, Mr. J. M. Vallance, Mrs. Chalmers Watson, Mr. J. R. Willis, Mr. E. H. T. Wiltshire. The secretaries of the Committee are: Mr. W. J. Peete, of the Ministry of Health, London, S.W.1, to whom all communications on the subject should be addressed; Mr. N. F. McNicoll, of the Department of Health for Scotland; 